\title{
ДОСВІД ВИКЛАДАННЯ МЕДИЧНОЇ БІОЛОГІЇ АНГЛОМОВНИМ СТУДЕНТАМ
}

\author{
ДВНЗ “Івано-Франківський національний медичний університет”

\section{EXPERIENCE OF TEACHING MEDICAL BIOLOGY TO ENGLISH- SPEAKING STUDENTS}

Л. С. Швець

\author{
L. S. Shvets
}

\author{
Ivano-Frankivsk National Medical University
}

\begin{abstract}
Використання англійської мови як мови вивчення медичної біології дало змогу розробити напрямки вдосконалення професійної майстерності викладацького складу кафедри та підвищення якості знань англомовних студентів. Досвід організації навчального процесу засвідчив необхідність постійного поновлення навчально-методичних та лекційних матеріалів даними сучасних досягнень науки і медицини. Створено посібник "Вибрані лекції з медичної біології" англійською мовою, який охоплює всі розділи дисципліни. Актуальним також є використання робочих зошитів для студентів, впровадження інноваційних технологій, підвищення якості тестового контролю, оволодіння практичними навичками та навичками наукової роботи.
\end{abstract}

The use of English as the language of Medical Biology study provided an opportunity to develop ways of improving professional skills of teaching personnel of the department and to improve the knowledge quality of English-speaking students. The experience of the educational process organization indicated the need for constant updating of learning and teaching and lecture materials with the data about modern science and medicine achievements. Study guide "Selected lectures on Medical Biology" was produced in English covering all course units. The use of workbooks for students, implementation of innovative technologies, improvement of control test quality, mastering practical skills of the research are also currently important.

Вступ. Викладання англійською мовою є актуальною проблемою вищих навчальних закладів (ВН3) України, оскільки за останні роки кількість іноземних студентів зростає [1]. Це дозволяє підвищити конкурентоспроможність ВНЗ на міжнародному ринку вищої медичної освіти. Використання англійської мови як мови викладання не лише ставить професійну майстерність професорськовикладацького складу на вищий щабель, але й активує міжнародне співробітництво, обмін, участь у грант-проектах, забезпечує можливість активно користуватися англомовними інформаційними ресурсами [2].

Формування клінічного мислення майбутнього спеціаліста вимагає глибоких знань фундаментальних дисциплін і медичної біології, яка перебуває на межі теоретичних і клінічних знань. Оскільки студенти вивчають медичну біологію впродовж першого курсу, складність організації іï̈ викладання англійською мовою полягає у: зміні соціального середовища; відсутності у студентів довузівської

(ㄱ Л. С. Швець адаптації; вирішенні питань мовної підготовки; “вирівнюванні” знань студентів, які приїхали 3 різних країн [3].

Доброзичливе ставлення до кожного іноземця, допомога у вирішенні їхніх проблем у період адаптації сприяють кращому взаєморозумінню між викладачем і студентом та підвищують якість освітнього процесу [4].

Враховуючи вищесказане, викладацький склад кафедри медичної біології і медичної генетики Івано-Франківського національного медичного університету (ІФНМУ) постійно працює над удосконаленням викладання медичної біології англомовним студентам в умовах кредитно-трансферної системи.

Метою статті $є$ аналіз досвіду викладання медичної біології англомовним студентам першого року навчання.

Основна частина. Навчальні програми з медичної біології а також зміни, які вносяться в них кожного навчального року, засвідчують необхідність удосконалення та поновлення всіх методичних матеріалів (змін і доповнень до робочих програм, 
методичних вказівок для студентів та викладачів). Тому щорічно велика робота проводиться із впровадження новітніх досягнень медицини, сучасних діагностичних технологій у педагогічний процес.

Основною ланкою у передачі інформації від викладача до студента залишаються лекції. Останні презентуються на мультимедійному проекторі та поєднують слайди різного характеру, фрагменти відеофільмів, що полегшує сприйняття навчального матеріалу. Окрім того, лекційний матеріал постійно поновлюється, використовується інтерактивна дошка. У презентаціях висвітлюються також дані досліджень науковців кафедри, які працюють за кордоном і надають сучасну літературу з різних розділів молекулярної біології, генетики та паразитології.

Календарно-тематичний план лекцій, який не охоплює всіх тем, передбачених навчальною програмою, та недостатня кількість англомовних підручників і посібників вимагають виготовлення додаткових матеріалів та консультацій. 3 урахуванням зменшення кількості лекцій з предмета для студентів медичного факультету нами написано навчально-методичний посібник “Вибрані лекції 3 медичної біології” англійською мовою, який редагується для подальшого затвердження Вченою радою ІФНМУ.

Досвід організації навчального процесу на практичних заняттях засвідчив необхідність використання таблиць, схем, ілюстрацій, фотографій та їх постійне оновлення. Окрім того, з ціллю інтенсифікації виконання завдань та економії робочого часу студентів викладацьким колективом кафедри виготовлені робочі зошити із запропонованими схемами, тестовими завданнями. Останні дозволяють скоротити час для проведення поточного і заключного контролю та підвищити його якість. Це сприяє кращому засвоєнню знань, запам’ятовуванню матеріалу.

На практичних заняттях з паразитології англомовні студенти готують презентації, в яких висвітлюють особливості захворювань, характерних для регіонів їх проживання (лейшманіозів, трипаносомозів, малярії, шистосомозів, анкілостомозів, філяріозів). Актуальними також є цікаві реферати з арахноентомології, оскільки велика кількість видів отруйних павуків та комах поширена на територіях із тропічним і субтропічним кліматом. Для цих презентацій студенти використовують музейні експонати та відеофрагменти. Останні та фотографії деяких препаратів паразитів, яких немає в достатній кількості на кафедрі, демонструються на практичних заняттях, оскільки всі навчальні кімнати оснащені телевізорами.

Формування клінічного мислення у майбутніх спеціалістів неможливе без оволодіння студентами практичними навичками та вміннями, розв’язування ситуаційних задач у процесі вивчення медичної біології. Колектив кафедри медичної біології та медичної генетики розробив перелік практичних навичок і вмінь та алгоритми їх виконання англійською мовою. Для кращого засвоєння останніх практикується проведення ділових ігор. Участь ІФНМУ впродовж чотирьох років у міжнародному проекті “Mumeena” сприяє якісному оволодінню студентами практичними навичками. До переліку останніх входять: робота із світловим мікроскопом, виготовлення тимчасових препаратів, робота у генетичній лабораторії (ознайомлення 3 різними методами генетики людини), визначення паразитів.

Майбутні лікарі повинні постійно набувати нову наукову інформацію та нові навички, якщо хочуть залишатись компетентними. Участь у міжнародному проекті “Mumeena” надає студентам, які проходять курс переддипломної освіти, в тому числі на факультеті підготовки іноземних громадян, можливість здобути, розвинути та застосувати навички наукової роботи [5]. Для цього на кафедрі створена бібліотека сучасної англомовної літератури, що дозволяє студентам набувати навички пошуку та критичної оцінки нової інформації. Окрім того, іноземні студенти мають доступ до інтернет-бібліотеки ІФНМУ.

Студентам пропонується підготувати реферати з ціллю ознайомлення із сучасними напрямками в розвитку медицини. В перспективі планується залучати іноземних студентів до НДРС, участі у міжнародних конференціях.

Навички наукової роботи, підготовка рефератів та презентацій, є вагомим аспектом мотивації отримання додаткових балів.

Проте пріоритетним методом для оцінювання знань студентів є тестовий контроль, в якому використовуються завдання з банку ліцензійного іспиту “Крок-1”. Тестування забезпечує індивідуальну роботу кожного студента, підвищує їі якість. В підготовці тестових завдань викладацький склад кафедри враховує вимоги і рекомендації, які запроваджені проектом “Mumeena” [5]. Тестування та контроль засвоєння практичних навичок здійснюється у два етапи: на поточному практичному 
занятті та на підсумкових модульних контролях. Всі види завдань оцінюються балами за відповідною шкалою.

Для покращання навчальної дисципліни та успішності на кафедрі для студентів англомовного відділення постійно проводяться консультації і відробки.

Висновки. Підвищення рівня знань англомовних студентів з медичної біології та досягнення більших успіхів у навчанні забезпечується: поновленням методичних та лекційних матеріалів; підготовкою посібника “Вибрані лекції з медичної біології” англійською мовою до затвердження

\section{Список літератури}

1. Мельничук I. М. Особливості викладання курсу “Історія української літератури” іноземним студентам-медикам / I. М. Мельничук, Л. М. Романишина, О. В. Яцишина // Наукові записки. Серія “Педагогіка”. - 2012. - № 2. - С. 114-118.

2. Проблемні аспекти англомовного навчання в медичних вузах України / В. К. Ліхачов, Л. М. Добровольська, Т. Ю. Ляховська [та ін.] // Світ медицини та біології. 2013. - № 2. - С. 118-119.

3. Малахова С. М. Проблеми міжкультурної комунікації іноземних студентів: педагогічні аспекти України /
Вченою радою ІФНМУ; використанням робочих зошитів із запропонованими схемами, тестовими завданнями. Формуванню клінічного мислення сприяє впровадження інноваційних технологій (ділових ігор, мозкового штурму), підвищення якості тестового контролю, оволодіння практичними навичками та навичками наукової роботи у наукових лабораторіях кафедри.

Перспективи подальшого розвитку у даному напрямку полягають у використанні моделі “віртуальний пацієнт”, що особливо актуально на практичних заняттях з медичної генетики та паразитології.

С. М. Малахова // Медична освіта. - 2016. - № 1. C. $32-34$

4. Інноваційні технології та методологія викладання фтизіатрії студентам з англомовною формою навчання в умовах євроінтеграції медичної освіти / Л. І. Білозір, I. Г. Ільницький, О. П. Костик [та ін.] // Український пульмонологічний журнал. - 2013. - № 1. - С. 52-56.

5. Викладання і навчання навичкам наукової роботи протягом переддипломної освіти / Х. М. Пейнадо, Ф. І. Вульф, М. К. Ірібар, А.-М. Райд. Проект спонсорований Tempus. - Університет Лідса, 2015. - 114 с. 